\title{
S ] ПОЛИТИЧЕСКОЕ УЧАСТИЕ
}

Токарь Н.O.

\section{ПОЛИТИЧЕСКАЯ СОЦИАЛИЗАЦИЯ МОЛОДЁЖИ В УСЛОВИЯХ ДЕМОКРАТИЗАЦИИ РОССИЙСКОГО ОБЩЕСТВА}

\begin{abstract}
Аннотация: Развитие политической системы России, переход к правовому государству и гражданскому обществу непосредственно зависят от степени участия в этих процессах всех социальных групп, в том числе - молодёжи. Становление молодых людей как граждан неразрывно связано с проблемой политической социализации. Возрастание значения политической социализации вызывается, прежде всего, необходимостью сформировать в подрастающем поколении новые гражданские черты, правовую и политическую культуру. В статье анализируются основные формы и институты политической социализаџии молодёжи, благодаря которой она приобщается к демократическим иенностям. Автором делается вывод о том, что политическая сочиализация молодого поколения должна стать частью государственной молодёжной политики. При стабильной политической системе подготовка подрастающего поколения, включая его политическую сочиилизацию, позволит обеспечить сравнительно гармоничную передачу от поколения к поколению основных политических иенностей. Их освоение позволит молодёжи воспринимать существующую политическую власть и политическую систему как легитимные.
\end{abstract}

Review: Development of the political system of Russia, transfer to the rule-of-law state and civil society are dependent upon participation of all of the social groups, including the youth. Formation of the young people as citizens is closely connected with the political socialization problem. Growing value of the political socialization is due first of all to the need to form new civil characteristics, legal and political culture for the young people. The article includes analysis of the key forms and institutions of the political socialization of the youth, thanks to which the youth shall join in the democratic values. The author comes to a conclusion that political socialization of the youth should become a part of a state youth policy. In the conditions of a sustainable political system the education of the youth, including its political socialization, shall allow to guarantee a rather harmonic transfer of the key political values from the older generation to the younger generation. Their recognition shall allow the youth to recognize legitimacy of political power and political system.

Ключевые слова: асоциалиазиия, сочиальная дезадаптаџия, десоциализация, политическая социализаиия, система образования, семья, СМИ, политические партии, молодёжь, политическая культура

Keywords: a-socialization, social des-adaptation, de-socialization, political socialization, system of education, family, mass media, political parties, youth, political culture.

B современном мире всё более нарастающей проблемой становится оторванность молодёжи от общественно-политической жизни, причём жизненный уровень на это практически не влияет ${ }^{1}$.

\footnotetext{
${ }^{1}$ Константинова Л.В. Социальная политика: штрихи к со-
} циологической концепции СОЦИС. 2005. № 1. С.49
Отмечается рост такого явления, как «асоциализация», т.е., процесс усвоения личностью антиобщественных, антисоциальных норм, ценностей, негативных ролей, установок, стереотипов поведения, которые объективно приводят к деформации общественных связей, к дестабилизации общества. Наряду с понятием «асоциализация» личности широко используется термин «со- 
циальная дезадаптация»². Для характеристики поведения молодёжи в общественно-политической жизни употребляют понятия «десоциализация» и «отставание в социализации». Первый означает, что на определенной стадии нормальной социализации личности происходит ее некоторая деформация, когда она попадает под влияние (стихийное или целенаправленное) отрицательной микросреды - дворовой компании сверстников, преступной группы и т.п. В результате этого у личности происходит разрушение прежних позитивных норм и ценностей, взамен которых усваиваются новые антиобщественные нормы и ценности, образцы поведения.

Отставание в социализации, не будучи антиобщественным, может со временем привести (и часто приводит) к усвоению личностью негативных норм или к бездумному подчинению такой отставшей в социализации личности воле других антиобщественных элементов.

В политической науке часто одним из наиболее эффективных методов утверждения лояльности населения к власти признаётся демократизация: она обеспечивает приход во власть свежих сил, в тоже время обеспечивает преемственность поколений, сохраняя лучшие традиции и накопленный опыт. Но в западно-европейской и американской литературе отмечаются и слабые места демократической модели развития: общество потребления фактически как обязательная экономическая основа демократии неизбежно порождает политическую апатию. Для определения этого парадоксального явления используется термин «социальный маугли», когда индивид не приобретает навыков общественно-политической активности, при материальном достатке господствует «политическая нищета» ${ }^{3}$. В связи с этим признаётся отсутствие некой идеальной или универсальной модели политической социализации.

Выделяются разные типы социализации. Гомогенный тип - предполагает наличие однородной культурной среды, определённых демократических традиций и гражданского общества - характерен для Великобритании и США. Плюралистическому типу присущ опосредующий характер взаимодей-

${ }^{2}$ Деркач А.А. Социальная психология. - М., «Высшая школа», 2001

${ }^{3}$ Youth as a key priority of the Alliance of Civilizations // European Journal on Child and Youth Policy. № 13. June. 2009. P. 24. ствия личности с властью, где наличие значительного числа разнородных субкультур предполагает первоначальную политическую социализацию индивида в границах идеалов и ценностей своей культурно-этнической группы, здесь действует консолидированная демократия: такая модель характерна для стран Западной Европы. Общества так называемого «третьего» мира характеризуются конфликтным типом политической социализации: высокий уровень нищеты большинства населения, высокая степень политического насилия, усвоение индивидом местнических ценностей и норм политической жизни всегда осуществляется в жесткой борьбе с носителями иных политических субкультур. Выделяют также гегемонистский тип политической социализации, предполагающий вхождение человека в политику исключительно на ценностях какого-либо класса, определенной религии или политической идеологии. Этот тип политической социализации характерен для закрытых политических систем, которые критически относятся к ценностям иных систем.

Под политической социализацией в современной политической науке понимается процесс усвоения человеком норм, традиции политической культуры, способствующих формированию у него необходимых качеств и свойств для адаптации к данной политической системе и выполнению там определенных функций и ролей ${ }^{4}$. Её главная цель - включение индивида в существующую политическую систему. В современных условиях существуют три основные формы политической социализации: 1) целенаправленная, т.е. сознательное стремление индивида в политику; 2) стихийная, когда человек увлекается политикой в силу случайных обстоятельств; 3) воспитательно-образовательная, в которой интерес к политике является результатом формирования гражданского сознания под воздействием воспитания и образования ${ }^{5}$. Мотивы во всех формах могут быть самыми разными: любопытство, желание изменить и улучшить окружающий мир, стремление к власти и т.д.

\footnotetext{
${ }^{4}$ Политическая наука: Словарь-справочник. сост. проф. полит. наук Санжаревский И.И.. 2010. Режим доступа: http:// dic.academic.ru/dic.nsf/politology/2688 [31.05.2013]

5 Ольшанский Д.В. Основы политической психологии. Режим доступа: http://www.gumer.info/bibliotek_Buks/Psihol/ Olsch/4_2.php [31.05.2013]
} 


\section{Политика и общество 8 (104) • 2013}

Период перестройки 80-х гг. и радикальных реформ 90-х гг. ХХ века сопровождался экономической и политической нестабильностью, слабостью государственной власть и многими другими отрицательными явлениями. Всё это создавало крайне отрицательный фон для политической социализации: более актуальными стали такие проблемы, как «добывание хлеба насущного» и поиск места в меняющейся жизни. И это несмотря на то, что лозунгом того времени стало построение гражданского общества и правового государства. В итоге получался замкнутый круг: оба заявленных института невозможны без политической социализации, но социально-экономические проблемы у большей части населения вытесняли все другие вопросы.

Всплеск политической активности во второй половине 80-х - начале 90-х XX века к середине 90-х сменился отрицательным отношением к любой политической активности ${ }^{6}$. СМИ того времени большей частью занимались поиском неудач политических лидеров и скандалов. Неудивительно, что в таких условиях, становление политического сознания молодого поколения оказалось замедленным.

К середине 2000-х гг. ситуация начала меняться: несколько улучшилось материальное положение, политические партии активизировали работу по привлечению молодёжи в свои ряды. Появились молодёжные политические организации относительно массового характера. Однако условия политической социализации улучшились ненамного. Формирование гражданина происходит в процессе политической социализации, когда человек усваивает определенную систему ценностей и ориентации, обретает навыки, необходимые для выполнения политических ролей, т.е. индивид получает определенный уровень знаний о политике, адекватный его политическим правам и обязанностям. И это не просто схема: происходит самоидентификация сначала с социальной группой, а потом и с нацией, т.е. обретается национальное сознание, представление о национальной идее.

Внутри российской элиты отсутствует согласие по поводу основных ценностей, несмотря на все усилия, так и не сформировалась государственная идеология. Высказывания с взаимными характери-

\footnotetext{
${ }^{6}$ Димов В.M. Проблемы девиантного поведения российской молодежи (социологический аспект)// Вестник МГУ. - 1997. - Сер. 18. Социология и политология. - № 3. - С. 45 - 76.
}

стиками сторонников консервативной, либеральной, национал-патриотической, левой ориентации напоминают больше лозунги времён Гражданской войны 1918-1922 гг., практически не содержат конструктивной критики политических оппонентов, как это принято в сложившихся политических системах. В таких условиях осознание молодыми гражданами принадлежности к политической системе, если и происходит, то в сильно деформированном виде.

Одним из традиционных каналов политической социализации молодёжи, обеспечивающим усвоение ей демократических ценностей, является система образования. В советский период здесь действовала монолитная идеологическая система политической социализации с чёткой иерархией детских и молодёжных организаций (важнейшие - пионерия и комсомол). Вполне сознательной целью являлось формирование однородных политических убеждений. В 90-е гг. ХХ века вместе с монополией коммунистической идеологии оказалась разрушенной и система воспитания гражданских качеств. Формально объявлен политический и идеологический плюрализм, на деле образовался духовный вакуум, куда хлынули крайне радикальные политические и религиозные учения сектантского толка или просто криминальная психология со специфическими ценностями. Зачастую и сами педагоги оказались в состоянии политической ресоциализации ${ }^{7}$. Для общества и государства это выразилось в резком росте преступности и наркомании среди молодёжи.

Попыткой решить эту проблему стало введение различных общественно-политических курсов, одним из которых стало обществознание, вошедшее в перечень ЕГЭ. Задачей курса стала консолидация разрозненных знаний основы права, политологии, социологии, психологии. Особое внимание в этих курсах уделяется государственному и политическому устройству Российской Федерации, реформам административной и политической системы страны, проблемам политических прав и свобод граждан, роли различных общественных организаций и т.д. Однако до настоящего времени сохраняется разнобой в подходах и мнениях по этим вопросам.

\footnotetext{
${ }^{7}$ Рубчевский К.В. Социализация личности: интериоризация и социальная адаптация // Общественные науки и современность. 2003. №3. С.149
} 
Другим традиционным каналом осталась семья. Несмотря на определенные различия во взглядах и идеалах у представителей разных поколений существует определенная преемственность. Родители и другие родственники по-прежнему оказывают сильное влияние на участие или неучастие молодёжи в политической жизни, формирование политического сознания. При этом немаловажное влияние на формирование политических ориентаций оказывает социально-экономическое положение семьи.

Мощнейшим каналом политической социализации молодёжи являются средства массовой информачии. Как указывалось выше, в 90-е гг. СМИ создали скорее отталкивающий образ, как политики, так и политиков. Очень часто для этого имелись основания, но отсутствие положительных примеров и героев в противовес анти-героям в итоге объективно способствовало отчуждению молодёжи от власти и политики. В 2000-е годы ситуация несколько исправилась, появился социальный запрос на положительную информацию, на что СМИ отчасти сумели отреагировать. Однако в 2010-2012 гг. в связи с ростом протестных настроений (это показали и выборы в Государственную Думу в 2011 году и президентские выборы 2012 года), выступлениями политических движений, СМИ перешли на бинарный характер оценок: черноё - белое, плохие - хорошие. Это подстёгивалось и риторикой противоборствующих политических сил. Как для проправительственных, так и для оппозиционных сил были характерны высказывания тенденциозного и чисто эмоционального характера («возвращение к сталинщине», «продавшиеся госдепу и ЦРУ» и т.п. $)^{8}$. Всё это напоминало политические бои начала 90-х гг., закончившиеся печально известными событиями октября 1993 года.

Проявилась и другая тенденция: наиболее политически активная часть молодёжи стала чувствовать информационный голод в традиционных СМИ, появились даже обвинения в фактическом цензурировании ТВ, радио, газет и журналов. Но утверждения о скрытии «истинной информации» характерны как для сочувствующих правящему режиму, так и для считающих себя оппозиционерами,

8 Джаксыбаев A. М. Политическая социализация молодежи// IV Студенческий научный форум (15 февраля - 31 марта 2012 года). Режим доступа: http://www.rae.ru/forum2012/ [31.05.2013] только одни объясняют это происками иностранных спецслужб и их агентов в России, другие желанием властей «закрутить гайки» ${ }^{9}$. В итоге произошёл отток читающей аудитории в новый вид СМИ - глобальную сеть Интернет. Технические возможности интернет-пространства позволяют каждому, владеющим элементарными компьютерными навыками, высказаться в социальных сетях (Вконтакте, Facebook, Twitter), в блогах, сайтах, персональных страницах, видеохранилищах (Youtube) по любому вопросу, в силу этого Интернет воспринимается как наиболее демократический вид СМИ. Феномен «электронных революций» в настоящее время является объектом пристального изучения политологов, но для России можно уже сделать один вывод. Участвует в электронных обсуждениях, вероятно, меньшинство молодёжи, но меньшинство политически активное. Это люди, имеющие политическую позицию или считающие, что имеют таковую.

Наконец, каналом политической социализации являются политические партии. Основными задачами молодёжных партийных организации являются подготовка кадров для политической деятельности и доведение идей партии до будущих молодых избирателей, формирование общественного мнения. При этом молодёжные структуры политических партий ориентированы, в первую очередь, на мобилизацию и рекрутирование молодёжи, обеспечение широкой электоральной поддержки «материнским партиям» ${ }^{10}$.

Таким образом, решение задач политической социализации молодёжи требует своего комплексного решения. Наиболее перспективными направлениями представляются: формирование целенаправленной молодёжной политики, поощрение практики молодёжного волонтёрства в общественных проектах, налаживание систематического диалога власти, особенно местной, с молодёжью, увязывание избирательного процесса с решением специфических молодёжных проблем. Основыва-

\footnotetext{
${ }^{9}$ Цензура в современной России// Сайт «Славяне». Режим доступа: http://nfor.org/stati/politika-i-obschestvo/cenzura-vsovremenoi-rosi.html. [31.05.2013] Гольнко-Вольфсон Д. Поцелуй милиционера: есть ли в России (био)политическая цензура?// Сайт «Журнальный Зал». Режим доступа: http:// magazines.russ.ru/nz/2008/1/vo15.html [31.05.2013]

${ }^{10}$ Самаркина И.В. Функции молодежных структур политических партий: социализация или мобилизация? // Социально-гуманитарные знания. 2008. № 11. С. 30
} 


\section{Политика и общество 8 (104) • 2013}

ясь на этих направлениях, современная политическая элита будет вправе рассчитывать на появление политически активной и при этом лояльной власти молодёжи. Именно это сможет обеспечить стабильное развитие общества и государства.

\section{Библиография:}

1. Деркач А.А. Социальная психология. - М., «Высшая школа», 2001

2. Димов В.М. Проблемы девиантного поведения российской молодежи (социологический аспект)// Вестник МГУ. - 1997. - Сер. 18. Социология и политология. - №

3. Константинова Л.В. Социальная политика: штрихи к социологической концепции СОЦИС. 2005. № 1 .

4. Рубчевский К.В. Социализация личности: интериоризация и социальная адаптация // Общественные науки и современность. 2003. №3.

5. Самаркина И.В. Функции молодежных структур политических партий: социализация или мобилизация? // Социально-гуманитарные знания. 2008. № 11.

6. Youth as a key priority of the Alliance of Civilizations // European Journal on Child and Youth Policy. № 13. June. 2009.

7. Голынко-Вольфсон Д. Поцелуй милиционера: есть ли в России (био)политическая цензура?// Сайт «Журнальный Зал». Режим доступа: http://magazines.russ.ru/nz/2008/1/vo15.html [31.05.2013]

8. Джаксыбаев А. М. Политическая социализация молодежи// IV Студенческий научный форум (15 февраля-31 марта 2012 года). Режим доступа: http://www.rae.ru/forum2012/ [31.05.2013]

9. Ольшанский Д.В. Основы политической психологии. Режим доступа: http://www.gumer. info/bibliotek_Buks/Psihol/Olsch/4_2.php [31.05.2013]

10. Политическая наука: Словарь-справочник. сост. проф. полит. наук Санжаревский И.И.. 2010. Режим доступа: http://dic.academic.ru/dic. nsf/politology/2688 [31.05.2013]
11. Цензура в современной России// Сайт «Славяне». Режим доступа: http://nfor.org/stati/ politika-i-obschestvo/cenzura-v-sovremenoi-rosi. html. [31.05.2013]

12. Щупленков О.В., Щупленков Н.О. Политическая социализация и идентичность в условиях трансформации российского общества // NB: Проблемы общества и политики. - 2013. - 6. - C. 1-58. URL: http://www.e-notabene.ru/pr/article_724.html

\section{References (transliteration):}

1. Derkach A.A. Social'naya psihologiya. - M., «Vysshaya shkola», 2001

2. Dimov V.M. Problemy deviantnogo povedeniya rossiyskoy molodezhi (sociologicheskiy aspekt)// Vestnik MGU.-1997.-Ser. 18. Sociologiya i politologiya. - №

3. Konstantinova L.V. Social'naya politika: shtrihi k sociologicheskoy koncepcii SOCIS. 2005. № 1.

4. Rubchevskiy K.V. Socializaciya lichnosti: interiorizaciya i social'naya adaptaciya // Obschestvennye nauki i sovremennost'. 2003. №3.

5. Samarkina I.V. Funkcii molodezhnyh struktur politicheskih partiy: socializaciya ili mobilizaciya? // Social'no-gumanitarnye znaniya. 2008. № 11 .

6. Golynko-Vol'fson D. Poceluy milicionera: est' li v Rossii (bio)politicheskaya cenzura?// Sayt «Zhurnal'nyy Zal». Rezhim dostupa: http://magazines.russ.ru/nz/2008/1/vo15.html [31.05.2013]

7. Dzhaksybaev A. M. Politicheskaya socializaciya molodezhi// IV Studencheskiy nauchnyy forum (15 fevralya-31 marta 2012 goda). Rezhim dostupa: http://www.rae.ru/forum2012/ [31.05.2013]

8. Ol'shanskiy D.V. Osnovy politicheskoy psihologii. Rezhim dostupa: http://www.gumer.info/bibliotek_Buks/Psihol/Olsch/4_2.php [31.05.2013]

9. Schuplenkov O.V., Schuplenkov N.O. Politicheskaya socializaciya i identichnost' v usloviyah transformacii rossiyskogo obschestva // NB: Problemy obschestva i politiki.-2013.-6.-C. 1-58. URL: http://www.e-notabene.ru/pr/article_724.html 